\title{
A and B mode ultrasonography in preoperative evaluation of lens and posterior segment of dogs eyes with cataract ${ }^{1}$
}

\begin{abstract}
Bianca C. Martins ${ }^{2}$, Emilio F. Rodrigues Jr², Ana L.G. Souza², Denise E. Almeida $^{3}$, Fábio L.C. Brito ${ }^{4}$, Júlio C. Canola ${ }^{2}$, Dennis Brooks ${ }^{5}$ and José L. Laus ${ }^{*}$

ABSTRACT.- Martins B.C., Rodrigues Jr E.F., Souza A.L.G., Almeida D.E., Brito F.L.C., Canola J.C., Brooks D. \& Laus J.L. 2010. A and B mode ultrasonography in preoperative evaluation of lens and posterior segment of dogs eyes with cataract. Pesquisa Veterinária Brasileira 30(2):121-126. Departamento de Clínica e Cirurgia Veterinária, Faculdade de Ciências Agrárias e Veterinárias, Universidade Estadual Paulista, Jaboticabal, SP 14884-900, Brazil. E-mail: jllaus@fcav.unesp.br

Ultrasonography of the lens and posterior segment is an indispensable step in the preoperative evaluation of dogs with cataracts, since ophthalmoscopy is not feasible when there is opacification of the lens. This study evaluated the echographic conditions of cataractous lens and fundus of the eye in dogs affected by cataracts. The study was conducted in 30 dogs (56 eyes), 10 males and 20 females, with different types of cataracts at different stages of development. Echography in A and B modes, simultaneously, was carried out for the examination of the lens and posterior segment. The examinations revealed anterior cortical, posterior cortical and nuclear cataract in 12 eyes (21.4\%), anterior cortical, posterior cortical, nuclear and posterior capsular in 23 eyes $(41 \%)$, anterior cortical, posterior cortical and posterior capsular cataract in one eye (1.7\%), anterior cortical and nuclear cataract in one eye (1.7\%), anterior cortical, nuclear and posterior capsular cataract in five eyes (8.9\%), and anterior cortical cataract in seven eyes (12.5\%). Abnormal ultrasonographic alterations were observed in the posterior segment in 26 eyes evaluated $(46.4 \%)$. Vitreal degeneration was detected in 12 eyes (21.4\%), images of vitreal exudate or hemorrhage in seven eyes $(12.5 \%)$, persistence of hyaloid artery in four eyes $(7.1 \%)$ and lens subluxation in three eyes $(5.3 \%)$. The results obtained reiterate the importance of ultrasonography in canine patients presented for cataract surgery given that alterations of the posterior segment are difficult to identify in a clinical examination when the lens is opacified.
\end{abstract}

INDEX TERMS: Ultrasonography, eye, cataract, dogs.

RESUMO.- [Ultrassonografia em modo A e B na avaliação pré-operatória da lente e do segmento posterior de olhos de cães com catarata.] A ultrassonografia do

\footnotetext{
${ }^{1}$ Received on July 10, 2009.

Accepted for publication on August 27, 2009.

2 Faculdade de Ciências Agrárias e Veterinárias, Universidade Estadual Paulista (Unesp), Via de Acesso Prof. Paulo Donato Castellane $\mathrm{s} / \mathrm{n}$, Jaboticabal, SP 14884-900, Brazil. *Author for correspondence: illaus@fcav.unesp.br

${ }^{3}$ Department of Internal Medicine, University of Michigan, Ann Arbor, MI, USA.

${ }^{4}$ Universidade Federal Rural de Pernambuco (UFRPE), Unidade Acadêmica de Garanhuns, Rua Ernesto Dourado 82, Heliópolis, Garanhuns PE 55296-280, Brasil.

${ }^{5}$ University of Florida, Department of Small Animal Clinical Sciences, Gainesville, FL, USA.
}

segmento posterior do bulbo do olho é etapa indispensável na avaliação de cães com catarata que serão submetidos à facectomia, uma vez que a oftalmoscopia não é factível quando há opacificação da lente, notadamente nas cataratas maduras. Este estudo avaliou as condições ecográficas da lente cataratogênica e do fundo de olho de cães cursando com catarata. Foram avaliados 30 cães (56 olhos), sendo 10 machos e 20 fêmeas, cursando com catarata em diferentes estágios de desenvolvimento. Realizou-se a ecografia em modo A e B simultaneamente. Os exames revelaram catarata cortical anterior, posterior e nuclear em 12 olhos (21,4\%), catarata cortical anterior, posterior, nuclear e capsular posterior em 23 olhos (41\%), catarata cortical anterior, posterior e capsular posterior em um olho $(1,7 \%)$, catarata cortical anterior e nuclear 
em um olho $(1,7 \%)$, catarata cortical anterior, nuclear e capsular posterior em cinco olhos (8,9\%) e catarata cortical anterior em sete olhos (12,5\%). Alterações no segmento posterior foram observadas, à ultrassonografia, em 26 olhos avaliados (46,4\%). Degeneração vítrea foi detectada em 12 olhos $(21,4 \%)$, imagens compatíveis com exsudato ou hemorragia em sete olhos (12,5\%), persistência da artéria hialóide em quatro olhos $(7,1 \%)$ e subluxação da lente em três olhos $(5,3 \%)$. Os resultados obtidos reiteram a importância da ultrassonografia em cães candidatos à cirurgia de catarata, uma vez que o exame do segmento posterior do bulbo do olho é de difícil execução, devido à opacificação da lente.

TERMOS DE INDEXAÇÃO: Ultrassonografia, olho, catarata, cães.

\section{INTRODUCTION}

Cataracts are characterized by focal or diffuse opacification of the lens and/or the lens capsule. They are the main cause of blindness in dogs where they should be differentiated from other lenticular imperfections and nuclear sclerosis (Gelatt 1979, Laus et al. 2001, Kecová \& Necas 2004).

Cataracts can develop secondary to intraocular diseases such as glaucoma, luxation of the lens, chronic uveitis, progressive atrophy of the retina, diabetes mellitus and other endocrine illnesses, traumas, and nutritional conditions (Keil \& Davidson 2001, Wilkie et al. 2006).

Dogs over 13.5 years old usually have some degree of lens opacity and metabolic alterations have been reported in the lens of patients with cataracts, such as those related to disorganization of lens proteins, metabolic pumps, ionic concentrations, and antioxidants (Davidson \& Nelms 1998, Williams 2004).

Cataracts can be congenital, hereditary, senile, secondary to systemic diseases, such as diabetes mellitus, toxic and traumatic (Glover \& Constantinescu 1997). They can even be classified based on age of the patient (congenital, infantile, juvenile and senile), location of the opacification (capsular, subcapsular, zonular, cortical, nuclear, axial and equatorial), and with respect to appearance and stage of progression (incipient, immature, mature and hypermature) (Slatter 1990, Ferreira et al. 1997, Davidson \& Nelms 1998).

Cataracts are common in diabetic dogs and frequently result in loss of vision (Salgado et al. 2000, Landry et al. 2004). Diabetes mellitus induces cataracts of usually acute bilateral occurrence (Wilkie et al. 2006). Loss of vision under such conditions can develop rapidly. There are cases, however, in which cataracts can be transient (Campos et al. 2005).

In hypermature cataracts, enzymes are released from lens fibers leading to proteolysis notably in the cortex. The lysis of proteins and loss of fluid by the lens capsule induce a reduction in the size of the lens and an irregular appearance of the surface of the anterior capsule. Cortical areas in hypermature cataracts can show, under diffuse illumination, small bright crystalline particles from the degradation of fibers and proteins (Whitley et al. 1993, Davidson \& Nelms 1998).

Patients with cataracts can manifest other complications. Phacolytic uveitis is one of the most important and its pathogenesis is related to the exposure of the local immunity to lens proteins with concomitant immune-mediated humoral and cellular responses (Glover \& Constantinescu 1997).

In patients with hypermature cataracts, there can be multifocal and sub-capsular whitened plaques in the anterior or posterior capsule, or in both. There can be an increase in depth of the anterior chamber and evidence of phacolytic uveitis. Among the complications resulting from phacolytic uveitis, glaucoma and phthisis bulbi are the most commonly reported. (Slatter 1990, Davidson \& Nelms 1998).

Cataracts can also be associated with total or partial retinal detachment and alterations of the vitreous. Vitreal degeneration and detachment of the posterior vitreous and of the retina are common in eyes of dogs with mature or hypermature cataracts (Van der Woerdt el al. 1993, Davidson \& Nelms 1998).

The surgical techniques used for the extraction of the lens are discission and aspiration; intracapsular extraction; extracapsular extraction; extracapsular phacoemulsification and endocapsular phacoemulsification (Whitley et al. 1993). Nevertheless, phacoemulsification is the elective procedure for the removal of a cataract, since it has advantages compared to other procedures, providing more significant success rates (Gelatt 1979, Whitley et al. 1993, Yi et al. 2006). Notwithstanding, it does have disadvantages such as high cost, and especially in cases of mature cataracts where the nucleus has a firm consistency and a longer time is needed for its fragmentation, increasing the risks of postoperative complications (Özgencil 2005).

Phacoemulsification normally reduces surgical trauma where access to the lens is gained through a small incision on the ocular surface (Pereira et al. 1999, Özgencil 2005, Sigle \& Nasisse 2006). Moreover, it allows the most efficient removal of the lens material, minimizing endothelial damage (Özgencil 2005, Sigle \& Nasisse 2006).

The opacification of the capsule is one of the most common post-operative complications (Yi et al. 2006, Bras et al. 2006). Age and sex do not influence significantly the occurrence of opacification of the posterior capsule, but young animals and small and medium breeds have been seen to be the most affected (Bras et al. 2006).

Considering the frequency in which cataracts are manifested in dogs and the implicit difficulties relative to the examination of the fundus of the eye in these cases, the aim of this study was to use ultrasonography to evaluate the conditions of the cataratogenic lens and fundus of the eye in dogs affected by this lens disease. 


\section{MATERIALS AND METHODS}

The project was submitted to and approved by Committee of Ethics and Animal Welfare of the Faculdade de Ciências Agrárias e Veterinárias (FCAV), Universidade Estadual Paulista (Unesp), Campus de Jaboticabal, São Paulo, Brazil. Bioethics cares follow the guidelines from Association for Research in Vision and Ophthalmology - ARVO (National Institutes of Health Publications no. 85-23: Revised 1985). The research was conducted in the Unidade de Oftalmologia do Hospital Veterinário Governador Laudo Natel, Faculdade de Ciências Agrárias e Veterinárias (FCAV), Universidade Estadual Paulista (Unesp), Campus de Jaboticabal, São Paulo, Brazil.

Both, males and females, aged 3 to 14 years, with uni- or bilateral cataracts at different stages of development were studied. Routine clinical ophthalmic examination was performed including the Schirmer's tear test ${ }^{6}$, menace, pupillary, corneal and palpebral reflexes, slit lamp biomicroscopy ${ }^{7}$, applanation tonometry ${ }^{8}$, gonioscopy ${ }^{9}$, indirect binocular ophthalmoscopy ${ }^{10}$ and fluorescein test ${ }^{11}$.

Ultrasonography was performed using one- and twodimensional techniques in real time using equipment designed for ophthalmic examination ${ }^{12}$ with $\mathrm{A}$ and $\mathrm{B}$ mode probes and $\mathrm{a}$ sectorial mechanical transducer of $10 \mathrm{MHz}$. Images were printed using a video printer ${ }^{13}$ and thermal sensitive paper ${ }^{14}$.

Topical corneal anesthesia ${ }^{15}$ was administered and animals were positioned in sternal recumbency. The eyelids were manually held open and sterile gel was used as a contact medium for conduction between the transducer and the eye to be examined (Dziezyc et al. 1987). The transpalpebral technique was utilized. The transducer was positioned in the axial region and scanning was begun at the optic nerve. Next, it was positioned on the limbus and redirected to scan the entire globe. The lens was evaluated with respect to echogenicity. Alterations in the posterior segment were investigated and assessed.

The lens of each eye was classified as having hyperechoic or hypoechoic areas. Areas of normal appearance were classified as being anechoic. Moreover, the alterations could be classified based on localization of the opacity.

At the end of the procedures, the eyes were rinsed with sterile $0.9 \%$ sodium chloride solution and reexamined for the identification and treatment, if necessary, of iatrogenic corneal lesions resulting from the examination.

${ }^{6}$ Shirmer Tear Test strips $₫$, Ophthalmos Indústria Farmacêutica, Av. Brigadeiro Luiz Antonio 4790, São Paulo, SP.

${ }^{7}$ SL-14@, Kowa Optimed Inc., 20001 South Vermont Ave, Torrance, CA, USA.

${ }^{83}$ Tonopen XL®, Meditronic Ophthalmics, 6743 Southpoint Drive North, Jacksonville, FL, USA.

${ }^{9}$ Koeppe medium diagnostic lens $18 \mathrm{~mm} \circledast$, Ocular Ophthalmics Inc., Colony Park Business Center, Lynnwood, WA.

10 Oftalmoscópio binocular indireto $\mathrm{FOH}-5 \AA$, Eyetec Equipamentos Oftálmicos, Rua Miguel Petroni 1832, São Carlos, SP.

${ }^{11}$ Fluoresceína strips $®$, Ophthalmos Indústria Farmacêutica, Av. Brigadeiro Luiz Antonio 4790, São Paulo, SP

12 Ultrascan®, Alcon Surgical, 1800 Alton Parkway, Irvine, CA, USA.

${ }^{13}$ Video Impressora P90 W®, Mitsubishi Medical, 15 Whatney, Irvine, CA, USA.

14 Thermal paper $\mathrm{K} 65 \mathrm{HM}{ }^{\circledR}$, Mitsubishi, 15 Whatney, Irvine, CA, USA.

${ }^{15}$ Anestalcon®, Alcon Labs, Av. Nossa Senhora da Assunção 736, São Paulo, SP.

\section{RESULTS}

A total of 56 eyes of 30 dogs with cataracts were evaluated. Four dogs had a unilateral cataract. Five of the 30 animals (16.6\%) had diabetes mellitus which was already being controlled with insulin and appropriate diet at the time of ophthalmic examination. The axial diameter of the lens of these individuals was significantly greater compared to the other dogs $(p<0.01)$.

Clinically, mature cataract was diagnosed in 41 eyes $(73.2 \%)$. In these, biomicroscopic localization of cataract to the nucleus, posterior cortex and posterior lens capsule was impossible. Immature cataract was observed in 14 eyes $(25 \%)$ and hypermature cataract with resorption of the axial regions of the anterior cortex and of the nucleus was observed in 2 eyes of 1 dog (1.7\%). Although the axial diameter of the eyes affected by hypermature cataracts was greater $(8.6 \mathrm{~mm})$ compared to the animals with immature $(7.5 \mathrm{~mm})$ and mature $(7.4 \mathrm{~mm})$ cataracts, significant differences were not detected.

On clinical examination, a posterior capsular cataract was detected in one dog in both eyes. This could not be determined, however, in the other animals since the evaluation of the posterior capsule in these cases was impossible given the degree of opacification of the lenses.

Cataracts were found to be anterior cortical, posterior cortical and nuclear in 12 eyes (21.4\%), anterior cortical, posterior cortical, nuclear and posterior capsular in 23 eyes $(41 \%)$ (Fig.1A), anterior cortical, posterior cortical and posterior capsular in one eye (1.7\%), anterior cortical and nuclear in one eye (1.7\%), anterior cortical, nuclear and

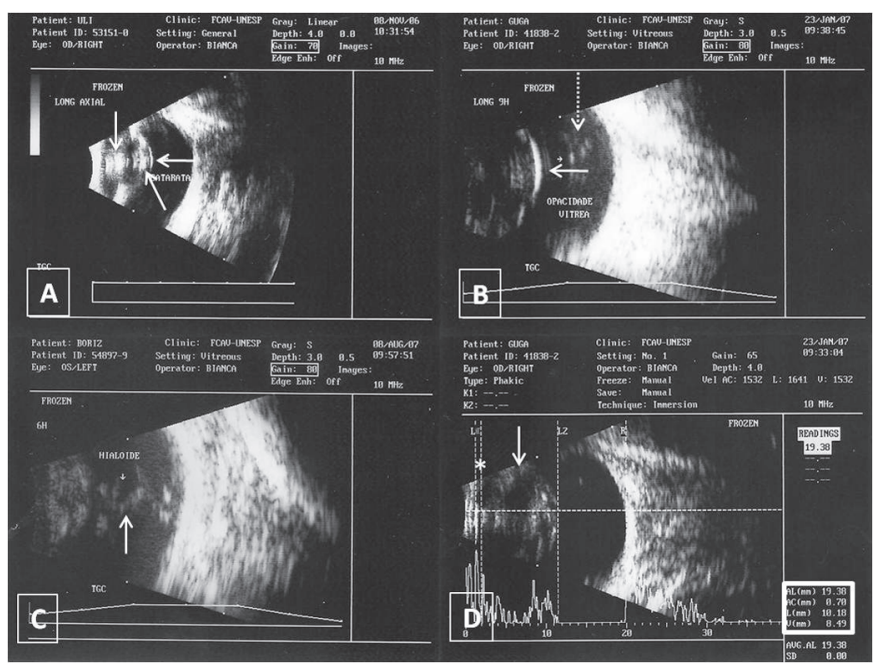

Fig.1. (A) Anterior cortex, equatorial and axial [arrow], posterior cortex [arrow], nucleus [arrow] and posterior capsule of lens, hyperechoic (complete cataract). (B) Posterior capsule lens, hyperecoic [filled arrow] and dotted hypoechoic reflections [dotted arrow] (focal opacity of vitreous). (C) Hyperechoic membrane adhered to posterior capsule of lens and to papillary area [arrow]. (D) On biometry [box], smaller anterior chamber $\left[{ }^{*}\right]$ (subluxation of lens) and increased diameter of lens [arrow] (diabetic cataract). 
posterior capsular in five eyes (8.9\%), and anterior cortical in seven eyes (12.5\%).

Different ultrasonographic alterations were observed in the posterior segment in 26 of the total eyes evaluated $(46.4 \%)$. These included dotted hypo-and hyperechoic reflections. The hypoechoic reflections were detected in 12 eyes $(21.4 \%)$. Of these, 11 occurred with mature cataract and one with immature cataract (Fig.1B).

Hyperechoic, intense, vitreal opacities compatible with exudate or hemorrhage were visualized in seven eyes (12.5\%), among which six exhibited mature cataract and one immature cataract. Cases of persistent hyaloid artery were observed in four eyes (7.1\%) (Fig.1C). Alterations that were compatible with sub-luxation of the lens were found in three eyes (5.3\%) (Fig.1D).

No sonographic images were observed that were compatible with total lens luxation, retinal detachment, tumors, foreign bodies, or persistence or hyperplasia of the primary vitreous. Furthermore, there were no iatrogenic lesions resulting from the examinations.

\section{DISCUSSION}

Cataracts are among the principle causes of visual impairment. Direct and indirect ophthalmoscopy permit a precise diagnosis when evaluating the posterior segment, but are ineffective in the face of opacification of transparent media of the eye, such as with mature cataracts (Slatter 1990). Often cataracts are at the mature or hypermature stage at the time of referral, precluding accurate assessment of the health of the posterior segment (Eisenberg 1985, Matton \& Nyland 1995, Narfstrom \& Ekesten 1998).

Electroretinography is a reliable and efficacious examination for the evaluation of retinal function. Nonetheless, there are cases, such as in partially detached retina, in which it may not contribute for diagnosis. It is imperative in these situations to utilize ultrasonography as a complementary diagnostic (Narfstrom \& Ekesten 1998).

Preoperative ultrasonography in cataract surgery, for example, contributes to satisfactory postoperative results making it useful for the evaluation of the posterior segment and with respect to the selection of patients who will be submitted to cataract removal (Eisenberg 1985, Matton \& Nyland 1995, Selcer 1995, Maggs 2008).

Regarding the stage of development of the cataracts in the present study, mature cataracts were found in the majority of eyes examined (73.2\%), notably in the older dogs, as has already been reported in the literature (Slatter 1990, Whitley et al. 1993, Honsho et al. 2002, Gelatt \& Mackay 2005). Immature cataracts were visualized in $25 \%$ of the eyes, similar to that found by Honsho et al. (2002) who observed an incidence of $17.2 \%$ in the cases they studied. Hypermature cataract was diagnosed in the present study in only one eye (1.8\%), contrary to $10.7 \%$ found by Honsho et al. (2002).

Animals with phacolytic uveitis, in the majority of cases, have reduced intraocular pressure (Leasure et al.
2001). In the present study, however, there was one animal with normal intraocular pressure and another with increased pressure, apparently compatible with glaucoma secondary to cataract. An in-depth retrospective study demonstrated that glaucoma secondary to cataract represented $81 \%$ of all the cases of secondary glaucoma in dogs (Gelatt \& Mackay 2004, Martins et al. 2006).

The aphakia encountered in two animals was due to prior cataract removals. Nonetheless in one of them there was opacity of the posterior capsule. According to Bras et al. (2006), opacity of the posterior capsule tends to be manifested during an average period of 2 to 4 months after cataract removal, independent of sex, age or presence of prior uveitis. It is recognized though that dogs of very large breeds tend to develop opacification of the posterior capsule in later periods compared to smaller breeds (Bras et al. 2006). It is known that opacity of the posterior capsule is caused by the proliferation and migration epithelial cells of the lens anterior capsule, and by fibroblasts, macrophages and pigments (Moore et al. 2003).

All the dogs in the present study easily tolerated twoand one-dimensional ultrasonography in real time. Furthermore, no iatrogenic lesions were observed as a result of the procedures, which confirmed that they were feasible and beneficial in the detection of structural and compartmental alterations of the eyes examined, for later interpretation.

In the majority of the animals, the hyperechogenicity of the anterior and posterior capsules was detected independent of the developmental stage of the cataract. The echogenicity of the lens contents varied from hypoechoic to hyperechoic in agreement with the developmental stage of the cataract. Such findings corroborate those of Scotty et al. (2004). With such aims in mind, one-dimensional ultrasonography in A mode was shown to be more advantageous compared to B mode (Matton \& Nyland 1995).

The mean axial diameter of the lens in the animals affected by immature $(7.5 \mathrm{~mm})$ and mature $(7.4 \mathrm{~mm})$ cataracts did not differ. Williams (2004), however, found that the axial diameter of the lens of dogs with mature cataract $(7.4 \mathrm{~mm})$ was greater, compared to cataract in immature $(6.4 \mathrm{~mm})$ and mature stages. Nevertheless, there were no discernible statistical differences between them. The author stated, in line to what was found in the present study, that the axial diameter of the lens in diabetic cataracts increases and that physiopathologic events peculiar to diabetic cataracts induce lens intumescence (Williams 2004).

The determination of the axial diameter was feasible with ultrasonography in A mode. For the majority of specialists, it involves a decision procedure for determining if such evaluation is desired (Matton \& Nyland 1995).

Vitreal degeneration and retinal detachment are common complications in animals with cataracts (Gelatt 1979, Whitley et al. 1993, Glover \& Constantinescu 1997, Davidson \& Nelms 1998). Clinically, degeneration involves 
the alterations related to the rupture of the vitreous. Such signs can include liquefaction (syneresis) and opacities (floaters, asteroid hyalosis and synchysis scintillant) (Boevé \& Stades 2007).

Syneresis is a condition in which the liquid component separates from the solid contents of the vitreous. It occurs with advancing age, but can result from complications such as inflammation (Boevé \& Stades 2007). In humans and cattle, it has been reported that the protective covering of vitreal fibrils, formed by collagen II and XI, diminishes with age. The event favors the fusion of vitreal fibrils vitreous and liquefaction. Small or large vitreal opacities result from accumulation of calcium and lipids, through the condensation of collagen fibrils, by erythrocytes and even by the accumulation of pigmented cells (including remnants of hyaloid artery) (Boevé \& Stades 2007).

Alterations were found in the vitreal chamber compatible with degeneration, exudate or hemorrhage in 19 of the eyes studied (33.9\%). Such findings support those reported earlier by Van der Woerdt et al. (1993), in which in $23 \%$ of the animals studied presented with these changes. Although imprudent to infer any correlation between alterations of the vitreous and conditions of the lens, notably with respect to the developmental stage of the cataracts, it was possible to observe the majority of the cases of opacification of the vitreous occurred with mature cataract (89.4\%). Van der Woerdt et al. (1993) showed that the percentage of eyes with alterations in the vitreous increased directly with maturation of the cataract (Van der Woerdt el al. 1993).

In ultrasonography, echoes are produced by the reflection of a sonographic wave on a tissue interface, generating different acoustic impedances (Matton \& Nyland 1995). The degree of vitreal liquefaction is variable, resulting in obstacles with different impedances. This leads to multiple lines or echogenic areas on the monitor. The detection of vitreal alterations depends on the degree of gain (calibration) of the equipment. Increases in gain allow the exposure of subtle alterations of echogenicity, facilitating the detection of abnormalities (Van der Woerdt el al. 1993).

Even though it is commonly viewed that retinal detachment may occur secondary to vitreal degeneration, this was not found in the present study (Dziezyc et al. 1987, Van der Woerdt el al. 1993, Narfstrom \& Ekesten 1998).

Failure of regression of the hyaloid artery constitutes an abnormality. It can persist in the vitreal cavity, where it resembles a fine thread produced by dense connective tissue, located between the optic disc and posterior capsule of the lens, and at times being filled with blood (Boevé \& Stades 2007). Four animals were found with cataracts and persistent hyaloid artery. The latter affliction is believed to be one of the causes of cataracts which result from the contact of remnants of the artery with the posterior capsule of the lens. Furthermore, it is considered as one of the most inductive abnormality in the posterior segment, inducing retinal detachments, vitreal opacification and detachment of the posterior vitreous, which is believed to result from the traction exerted (Van der Woerdt el al. 1993, Matton \& Nyland 1995, Davidson \& Nelms 1998).

Three cases of subluxation of the lens were identified in animals with mature cataracts. Consistent with what has been published on the subject, a cataract can induce fragility of the zonules (Eisenberg 1985).

Except for biometry, two-dimensional ultrasonography in $B$ mode has been shown to be more advantageous, compared to in A mode. The use of a $10-\mathrm{MHz}$ transducer in transcorneal and transpalpebral techniques has proved useful in the identification of the conditions of the lens and retina, even without the use of rubber sleeve technique. A recent study demonstrated that a $20-\mathrm{MHz}$ transducer does not offer additional benefits to ultrasonography of the lens of dogs and cats (Gorig et al. 2006).

In the present study, the results with respect to the conditions of the lens and fundus of the eye do not diverge from that reported in the literature which suggests that an electroretinogram and ultrasonography are valuable procedures prior to cataract removal and for the selection of patients who will be submitted to it (Van der Woerdt el al. 1993, Davidson \& Nelms 1998).

\section{CONCLUSION}

Ultrasonography is obligatory for a good selection of patients to be submitted to cataract surgery because it offers valuable information notably of the posterior segment not always visible by semiotic ophthalmic techniques.

Acknowledgements.- Financial support by FAPESP (Grant 05/590850) and CAPES (Fellowship).

\section{REFERENCES}

Boevé M.H. \& Stades F.C. 2007. Diseases and surgery of the canine vitreous, p.932-943. In: Gelatt K.N. (Ed.), Veterinary Ophthalmology. $4^{\text {th }}$ ed. Blackwell, Oxford.

Bras I.D., Colitz C.M.H., Saville W.J.A. \& Gemensky-Metzler A.J. 2006. Posterior capsular opacification in diabetic and nondiabectic canine patients following cataract surgery. Vet. Ophthalmol. 9:317327.

Campos C.F., Ferreira L.S., Souza M.G., Gama F.G.V., Laus J.L. \& Carciofi A.C. 2005. Catarata diabética transitória bilateral em um fiIhote de Terrier Brasileiro. Ciência Rural 35:709-712.

Davidson M.G. \& Nelms S.R. 1998. Diseases of the lens and cataract formation, p.818-828. In: Gelatt K.N. (Ed.), Veterinary Ophthalmology. $3^{\text {rd }}$ ed. Lippincott Williams and Wilkins, Philadelphia.

Dziezyc J., Hager D.A. \& Millcaamp N.J. 1987. Two-dimensional realtime ocular ultrasonography in the diagnosis of ocular lesions in dogs. J. Am. Anim. Hosp. Assoc. 23:501-508.

Eisenberg H.M. 1985. Ultrasonography of the eye and orbit. Vet. Clin. North Am., Small Anim. Pract. 15:1263-1274.

Ferreira F.M., Laus J.L. \& Jupa Junior C.J. 1997. Catarata em pequenos animais: classificação e tratamento. Braz. J. Vet. Res. Anim. Sci. 34:16-20.

Gelatt K.N. 1979. Lens and cataract formation in dog. Comp. Collect. 1:25-30.

Gelatt K.N. \& Mackay E.O. 2004. Secondary glaucoma in the dog in North America. Vet. Ophthalmol. 7:245-259. 
Gelatt K.N. \& Mackay E.O. 2005. Prevalence of primary breed-related cataracts in the dog in North America. Vet. Ophthalmol. 8:101-111.

Glover T.N. \& Constantinescu G.M. 1997. Surgery for cataracts. Vet. Clin. North Am., Small Anim. Pract. 27:1143-1173.

Gorig C., Varghese T., Stiles T., van den Broek J., Zagzebski J.A. \& Murphy C.J. 2006. Evaluation of acoustic wave propagation velocities in the ocular lens and vitreous tissues of pigs, dogs and rabbits. Am. J. Vet. Res. 67:288-295.

Honsho C.S., Oria A.P. \& Laus J.L. 2002. Uveíte induzida pelo cristalino em cães-prevalência em estudo retrospectivo. Clínica Vet. 39:1620.

Kecová H. \& Necas A. 2004. Phacoemulsification and intraocular lens implantation: Recent trends in cataract surgery. Acta Vet. Brno 73:8592.

Keil S.M. \& Davidson H.J. 2001. Canine cataracts: A review of diagnostic and treatment procedures. Vet. Med. 96:14-38.

Landry M., Herring I.P. \& Panciera D.L. 2004. Funduscopic findings following cataract extraction by means of phacoemulsification in diabetic dogs: 52 cases (1993-2003). J. Am. Vet. Med. Assoc. 225:709716.

Laus J.L., Bolzan A.A., Vicenti F.A.M., Santos C. \& Oria A.P. 2001. Terapia antiinflamatória na cirurgia de catarata pela facoemulsificação em cães. Hora Vet. 21:19-23.

Leasure J., Gelatt K.N. \& Mackay E.O. 2001. The relationship of cataract maturity to intraocular pressure in dogs. Vet. Ophthalmol. 4:273-276.

Maggs D.J. 2008. Basic diagnostic techniques, p.81-106 In: Maggs D.J., Miller P. \& Ofri R. (Eds), Slatter's Fundamentals of Veterinary Ophthalmology. $4^{\text {th }}$ ed. Saunders, Philadelphia.

Martins B.C., Vicenti F.A.M. \& Laus J.L. 2006. Síndrome glaucomatosa em cães, Parte 1. Ciência Rural 36:1952-1958.

Matton J.S. \& Nyland T.G. 1995. Ocular Ultrasonography, p.178-97. In: Nyland T.G. \& Matton J.S. (Eds), Veterinary Diagnostic Ultrasound. W.B. Saunders, Philadelphia.

Moore D.L., McLellan G.J. \& Dubielzig R.R. 2003. A study of the morphology of canine eyes enucleated or eviscerated due to complications following phacoemulsification. Vet. Ophthalmol. 6:219-226.
Narfstrom K. \& Ekesten B. 1998. Diseases of canines ocular fundus, p.860-873. In: Gelatt K.N. (Ed.), Veterinary Ophthalmology. $3^{\text {rd }}$ ed. Lippincott Williams and Wilkins, Philadelphia.

Özgencil F.E. 2005. The results of phacofragmentation and aspiration surgery for cataract extraction in dogs. Turk. J. Vet. Anim. Sci. 29:165173.

Pereira J.S., Pereira A.B.F.S. \& Martins A.L.B. 1999. Facoemulsificação: A técnica de escolha na extração de catarata. Revta Cães e Gatos 82:16-22.

Salgado D., Reusch D. \& Spiess B. 2000. Diabetic cataracts: Different incidence between dogs and cats. Schweizer Archiv für Tierheilkunde 142:349-353.

Scotty N.C., Cutler T.J., Brooks D.E. \& Ferrell E. 2004. Diagnostic ultrasonography of equine lens and posterior segment abnormalities. Vet. Ophthalmol. 7:127-139.

Selcer B.A. 1995. The eye, p.43-50. In: Cartee R.E. (Ed.), Practical Veterinary Ultrasound. Lea and Febiger, Philadelphia.

Sigle K.J. \& Nasisse M.P. 2006. Long-term complications after phacoemulsification for cataract removal in dogs: 172 cases (1995-2002). J. Am. Vet. Med. Assoc. 228:74-79.

Slatter D. 1990. Fundamentals of Veterinary Ophthalmology. $2^{\text {nd }}$ ed. W.B. Saunders, Philadelphia, p.371-378.

Van der Woerdt A., Wilkie D.A. \& Myer W. 1993. Ultrasonographic abnormalities in eyes of dogs with cataracts: 147 cases (1986-1992). J. Am. Vet. Med. Assoc. 203:838-841.

Whitley R.D., McLaughlin S.A., Whitlay E.M. \& Gilger B.C. 1993. Cataract removal in dogs: The surgical techniques. Vet. Med. 88:848-866.

Wilkie D.A., Gemensky-Metzler A.J., Colitz C.M.H., Bras I.D., Kuonen V.J., Norris K.N. \& Basham C.R. 2006. Canine A retrospective study of 18 dogs. Vet. Ophthalmol. 9:328-334.

Williams D.L. 2004. Lens morphometry determined by B-mode ultrasonography of the normal and cataractous canine lens. Vet. Ophthalmol. 7:91-95

Yi N., Park S., Jeong M., Kim W., Kim S., Chae J. \& Seo K. 2006. Phacoemulsification and acryl foldable intraocular lens implantation in dogs: 32 dogs. J. Vet. Sci. 7:281-285. 